\title{
Peningkatan Kecerdasan Terhadap Kinerja SDM Dengan IT Sebagai Variabel Moderating
}

\author{
Annisa Qurrota A'yun \\ Universitas Diponegoro \\ aqaannisa@lecturer.undip.ac.id
}

\begin{abstract}
This study aims to analyze the influence of intellectual, emotional, spiritual intelligence on HR performance with IT being moderate in an agency. The discussion of the importance of the influence of IT with intelligence to improve HR performance has been widely discussed in several literature studies. Although there are many other factors that affect the performance of primary schools, this study only discusses the existence of trust and commitment as determinants of HR performance. Data obtained from 63 respondents using a questionnaire. Data analysis using SPSS 17 shows that the performance of human resources in the agency can be improved by paying attention to the intelligence level of employees towards the agency. Intellectual, emotional, spiritual intelligence with IT as moderate have a positive and significant effect on HR performance.
\end{abstract}

Keywords: Intellectual Intelligence; Emotional Intelligence; Spiritual Intelligence; IT; HR Performance

\begin{abstract}
ABSTRAK
Penelitian ini bertujuan untuk menganalisis pengaruh kecerdasan intelektual, emosional, spiritual terhadap kinerja SDM dengan IT sebagai moderate di sebuah instansi. Pembahasan pentingnya pengaruh IT dengan kecerdasan untuk meningkatkan kinerja SDM telah banyak didiskusikan di beberapa kajian pustaka. Meskipun banyak sekali faktor-faktor lain yang mempengaruhi kinerja SD, penelitian ini hanya membahas tentang keberadaan kepercayaan dan komitmen sebagai penentu kinerja SDM. Data diperoleh dari 63 orang responden dengan menggunakan kuesioner. Analisis data dengan menggunakan SPSS 17 menunjukkan bahwa kinerja SDM di instansi tersebut dapat ditingkatkan memperhatikan tingkat kecerdasan pegawai terhadap instansi. Kecerdasan intelektual, emosional, spiritual dengan IT sebagai moderate memiliki pengaruh yang positif dan signifikan terhadap kinerja SDM.
\end{abstract}

\section{Kata Kunci : Kecerdasan Intelektual; Kecerdasan Emosional; Kecerdasan Spiritual; IT; Kinerja}




\section{PENDAHULUAN}

Organisasi yang efektif itu biasanya tergantung dari SDM yang tersedia, karena SDM adalah asset paling penting dalam sebuah organisasi. Dalam sebuah organisasi instansi di era sekarang (globalisasi), mengelola SDM merupakan hal terpenting dalam agenda organisasi. Definisi kinerja karyawan menurut Mathis (2009) yaitu hal-hal yang dilakukan oleh seorang karyawan untuk bisa mensukseskan organisasi. Keberhasilan suatu perusahaan dalam mengembangkan dan mengelola SDM biasanya akan menentukan kesuksesan sebuah organisasi dalam memenangkan persaingan dan mencapai tujuan, maka di perlukannya SDM berkualitas dengan memiliki intellectual intelligence yang tinggi. Salah satunya di perlukannya intellectual intelligence, dimana kercerdasan ini merupakan kategori kecerdasan yang akan menjadi pengolahan, penyimpanan, penerimaan sebuah informasi menjadi fakta (Widodo, 2012). (Boyatzis, 2001) dalam penelitiannya menemukan adanya factor-factor psikologis yang memiliki pengaruh terhadap kemampuan kerja SDM di suatu organisasi, yaitu mampu mengelola dirinya sendiri, insiatif, optimis, dan mampu mengendalikan emosinya dan juga mampu menenangkan diri sebagai dasar untuk mengambil keputusan ataupun untuk menyelesaikan suatu masalah dilingkungan kerja peruasahaan. Selain itu, menurut Estining Widyastini (2003) mengemukakan pada dasarnya seorang pemimpin itu membutuhkan sebuah kecerdasan selain kecerdasan intelektual, yaitu kecerdasan emosional karena seorang pemimpin itu yang akan memberikan contoh kepada karyawan nya dalam hal moralitas juga kedisiplinan dan harus mampu berinteraksi dengan baik diluar ataupun di dalam organisasinya. Menurut Patton (2008) mengatakan bahwa keefektifan dalam penggunaan emosi bisa menjadikan kebehasilan pekerjaan karena adanya hubungan yang produktif antar sesame karyawan. Selain intellectual intelligence \& emotional intelligence, ada juga spiritual intelligence yang sedang popular. Emmons (2000) mengemukakan bahwa sebuah masalah akan terpecahkan jika memiliki kecerdasan spiritual, dan karena itu seorang karyawan harus bekerja dengan baik dan iklas untuk kehidupan mereka. Di lain halnya, Sebuah Organisasi juga perlu memberikan perhatian khusus terhadap kemampaun pegawai dalam bidang teknologi informasi. Natigor (2004) ada beberapa factor yang mempengaruhi pengotimalan penggunaan IT, salah satunya yaitu ketersediaan perangkat. Penelitian ini dilakukan di BBWS pemali juana Semarang yang melaksanakan dan mengawal pembangunan infrastruktur di daerah. Dalam melaksanakan infrastruktur harus mempunyai SDM yang berkualitas, seperti halnya SDM tersebut harus mempunyai kecerdasan yang tinggi entah itu dari kecerdasan intelektual, emosinal maupun spiritual dan di dukung oleh teknologi informasi yang memadai. 
Dari hasil wawancara dapat diambil kesimpulan bahwa jika dilihat melalui kecerdasan emosional dimana kemampuan tersebut berkaitan dengan sikap seseorang, terlihat bahwadi Balai ini terdapat seringnya pegawai menunda pekerjaan atau tidak selesai tepat sesuai waktu yang telah ditetapkan yang diakibatkan oleh kesadaran diri dan motivasi yang kurang sehingga menyebabkan pegawai sering absen terhadap pekerjaan dan mengakibatkan kinerja pegawai dari BBWS pemali juana Semarang menjadi rendah dan kurang seimbang dengan jenis-jenis kecerdasan yang dimiliki. Jika dilihat melalui kecerdasan intelektual, kinerja pegawai sudah baik, bisa dibuktikan dengan tes masuk kepegawaian yang dilakukan dalam instasi ini. Karena syarat untuk bisa masuk menjadi pegawai di Instansi tersebut harus memiliki IPK diatas 3,00 juga nilai toefl diatas 450. Jika dilihat melalui kecerdasan spiritual, kinerja pegawai juga sudah baik, dapat buktikan dengan hasil tanya jawab atau wawancara yang dilakukan pada setiap Bagian/Bidang, bahwasanya SDM dalam instansi ini sangat taat melaksanakan ibadah dan memiliki rasa toleransi yang tinggi antar rekan kerja yang memiliki keyakinan yang berbeda. Melihat selarasnya kecerdasan intelektual dan kecerdasan spiritual, maka kecerdasan emosional pun harusnya dapat mengimbangi dua jenis kecerdasan tersebut karena ketiga jenis kecerdasan tersebut merupakan hal yang saling berkaitan dan ada dalam diri masing-masing individu. Instansi ini adalah yang melaksanakan tugas kenegaraan dan pelayanan masyarakat, dalam memastikan kinerja SDM unggul, perlu adanya penunjang dalam hal fasilitas pengetahuan IT. Teknologi informasi difasilitaskan kepada pegawai akan berpengaruh terhadap kecerdasan yang di miliki masing-masing SDM, dan selanjutnya hal ini akan berimplikasi terhadap peningkatan kinerja SDM. Maka dari itu perlu dilakukannya penelitian guna mengetahui pengaruhnya sejauh apa tentang intellectual intelligence, emotional Intelligence, spiritual intelligence terhadap kinerja SDM dengan dimoderasi teknologi informasi antara ketiga kecerdasan tersebut pada instansi ini, sehingga hasilnya dapat menjadi rekomendasi kepada instansi untuk dapat memelihara dan meningkatkan kinerja karyawan dalam organisasi.

\section{Kinerja SDM}

Mangkunegara (2001) mendifinisikan kinerja (prestasi kerja) sebagai hasil dari pencapaian kinerja pegawai yang yang sudah dengan baik melaksanakan tugasnya. Secara umum kinerja seorang karyawan itu adalah pencapaian yang diperoleh karyawan dalam mengemban tanggung jawabnya (didukung juga oleh penelitian dari Dewi dan Darma, 2017; Wiandari dan Darma, 2017).

(Guritno \& Waridin, 2005) menyebutkan beberapa indicator dalam kinerja SDM, yaitu: 
1) Kualitas dalam penigkatan target pekerjaan.

2) Tepat waktu dalam menyelesaiakan pekerjaan.

3) Selalu bertanggung jawab terhadap atas pekerjaan nya dengan selalu berinovasi.

4) Selalu memunculkan ide kreatif guna menunjang kuantitas kerja.

5) Efektif dan meminimalisir kesalahan dalam pekerjaan.

Sebuah output yang digabungkan dengan beberapa faktor seperti skill \& minat, juga mampu menerima jobdesc yang diberikan dengan tingkat motivasi yang tinggi disebut kinerja karyawan.

\section{Kecerdasan Intelektul}

Kecerdasan intelektual merupakan kecerdasan yang mencakup sebuah kenalaran, problem sloving, mampu memahami sebuah gagasan yang dimana menggunakan Bahasa dan mampu mempelajari (Mujib \& Muzakir, 2002). Kecerdasan ini isa diukur dengan menggunaka alat tes yang dinamakan intellegnce quotient, alat ini mampu mendeteksi seberapa mampu nya seorang karyawan dalam hal kecerdasan intelektual, karena kecerdasan intelektual sendiri merupakan suatu skill untuk memecahkan masalah dan kegiatan mental lainnya (Robbins, 2001). Pada tahun 1983 ada teori yang mengemukakan tentang kemampuan mental primer, dimana kemampuan ini merupakan kombinasi dari mental independen dan dari mental general. Ada beberapa primer skill, yakni:

1) Penguasaan kosakata

2) Angka

3) Non verbal

4) Memory

5) Nalar

6) Jarak atau ruang

7) Kecepatan dalam perseptualisasi

\section{Hubungan kecerdasan intelektual terhadap kinerja SDM}

(Wiramiharja, 2003) didalam penelitiannya menemukan hasil pengaruh positif signifikan antara kecerdasan yang lebih bersifat kognitif dengan sebuah prestasi dalam kinerja. Disebutkan bahwa kinerja SDM yang memiliki prestasi kerja yang baik mampu meningkatkan kinerja nya. Kontribusi kecerdasan intelektual dalam penelitian ini sebesar 30\%, dengan menggunakan kemampuan indicator sebagai berikut:

1) Figure 
2) Verbal

3) Numerik

Dan dalam penelitian ini (Wiramiharja, 2003) munjukkan hasil korelasi yang memberikan kesimpulan:

HI: Kecerdasan intelektual berpengaruh terhadap kinerja SDM.

\section{Kecerdasan Emosional}

Awangga (2006) mengatakan sebuah kecerdasan emosional diidentifikasi dengan mengenali isyarat dan atau perilaku, intropeksi diri dalam menyelesaikan sebuah masalah. Perilaku disini dimaksudkan meliputi sebuah skill nonverbal \& bisa juga verbal. Ada teori mengenai emotional intellegencia, yaitu teori peristiwa afektif. Terdapat sebuah model yang dikemukakan oelh Robbins \& judge (2003) bahwa suatu reaksi emosional bisa mempengaruhi perilaku seorang karyawan. Disebutkan dalam AET bahwasannya perilaku karyawan juga kadang terjadi sangat emosional diwaktu tertentu ditempat kerja. Kadang juga itu sebabkan karena emosi yang terpicu dari berbagai hal (Robbins \& Judge, 2008). Jika di artikan kesimpulannya emotional intellgencia itu merupakan sikap atau perilaku yang harus kita punya dan harus bisa kita kendalikan disaat emosi sedang tinggi-tingginya, dilain itu juga untuk memotivasi diri kita sendiri terhadap situasi yang ada.

\section{Hubungan kecerdasan emosional terhadap kinerja SDM}

Seorang peneliti terdahulu Rons.S (2001) dalam judulnya "unleashing the power of self directed learnig" menerangkan bahwa dalam penelitian yang menggunakan studi longitudinal dan juga menggunakan kuesioner menghasilkan pengaruh positif signifkan antara bakat seseorang dengan kemampuan dalam memperbaiki emosi. Terdapat 5 kecakapan dasar dalam mencapai suatu kesuksesan didunia kerja, dimana indicator ini dapat mengelola emosi diri sendiri secara efektif dan juga berpengaruh positif terhadap orang lain (Daniel Goleman, 2000), yaitu:

1) Sel awareness

2) Motivation

3) Emphaty

4) Relationship management

5) Self management

Dengan adanya uraian diatas maka disimpulkan hipotesis bahwa:

H2: kecerdasan emosional memiliki pengaruh terhadap kinerja SDM 


\section{Kecerdasan Spiritual}

Intellegencia spiritual menurut Robert Emmons (2000) yaitu suatu informasi rohani yang digunakan untuk menjadi problem solving sehari-hari untuk mencapai suatu tujuan. Agustin (2001) mengatakan bahwa peran spiritual intellegencia itu diperlukan bagi intellectual intellegencia dan juga emotional intellegencia. Jelas bahwa spiritual intellegencia itu adalah suara hati ilahyah yang dapat menjadikan sesorang itu berpikir akan melakukan suatu tindakan atau tidak. Jika kecerdasan intelektual berpusat di akal, kecerdasan emosional terpusahat pada hati, dari hal itulah kecerdasan spiritual terpusat pada hari nurani. (Agustian, 2001) mendifinisikan kecerdasan spiritual sebagai kemampuan yang bersifat fitrah, artinya lebih menuju yang fitrah dan mampu berfikir integralistik yang berprinsip kepada Allah. Definisi lain dari (Agustina, 2003) menjelaskan bahwa kecerdasan spiritual mampu memberikan makna spiritual terhadap setiap perilaku yang diukur dengan:

1) Kefitrahan seseorang dalam berperilaku

2) Memiliki kualitas hanif (baik)

3) Ikhlas dalam melakukan segala hal.

\section{Hubungan kecerdasan spiritual terhadap kinerja SDM}

(Sinamo, 2002) mengungkapkan bahwa seseorang yang mencintai perkerjaannya dianggap sebagai bentuk rasa syukur kepada Tuhan dalam wujud syukur kepada Negara, pemilik modal dan manajemen serta lingkungan dimana seseorang tersebut bekerja. (Zohar \& Marshall, 2001) menguji kecerdasan spiritual dengan indikator-indikator sebagai berikut:

1) Fleksibel dalam segala hal

2) Memiliki kesadarann diri yang tiggi

3) Mampu mengatasi dan menghadapi situasi apapun (tidak putus asa, rajin berdoa)

4) Ikhlas /pemaaaf

5) Prinsip hidup yang jelas

6) Berfikir sebelum bertindak

7) Berfikir logis

Penelitian diatas menunjukkan kesimpulan bahwa:

H3: kecerdasan spiritual memiliki pengaruh terhadap kinerja SDM. 
IT

(Tjhai, 2003) mengadopsi sebagian teori dari Triandis (1980) lalu dikembangkan dengan model dari Thompson et al. (1991), mengemukakan bahwa ada beberapa factor yang dimana IT dapat dipengaruhi dalam pemanfaatannya, yaitu:

1) Factor social (dukungan rekan kerja, lingkungan, organisasi)

2) Affect (perasaan individu nyaman menggunakan IT)

3) Kesesuaian tugas

4) Konsekuensi jangka panjang (apakah memberikan dampak positif/negatif)

5) Kondisi yang memfasilitasi pemanfaatan IT

6) Kompleksitas (tingkat inovasi yang sulit untuk di mengerti).

Indicator IT menurut sarosa \& zowgi (2003) dalam electronic journal of information system evaluation vol.6 issue 2 pp. 165-176, istilah IT dimaksudkan sebagai alat yang digunakan untuk mengumpulkan memproses dan juga menyebarkan informasi, adapun indicator pengukuran IT yaitu:

1) Intensitas IT

2) Tenaga ahli yang tersedia

3) Teknologi yang diinvestasikan

4) Informasi yang mudah dalam pertukaran informasi

5) Kerjasama yang memudahkan.

\section{Hubungan IT terhadap kecerdasan intelektual, emosional, spiritual dengan kinerja SDM.}

Penelitian Goodhue (1995) dalam (Tjhai 2003) menyebutkan bahwa suatu IT mampu memberikan pengaruh positif terhadap kinerja SDM, maka dari itu IT harus dimanfaatkan dengan benar juga didukung dengan tugas yang dikerjakan. (Sharma \& Arogan-Corera, 2008) Dalam perkembangan dinamika IT terdapat beberapa teori yang mengemukakan perihal IT yaitu salah satunya teori contingency yang menyebutkan bahwa kinerja organisasi itu adalah hasil dari penyesuaian variable internal dengan variable lingkungan. Diperlukan intensitas pembuatan keputusan guna membedakan intensitas keragaman lingkungan, karena hal itu disesuaikanlah lingkungan dengan sumber-sumber dari organisasi. Dari temuan lain Mamaghni (2010) terdapat IT yang memoderasi antara intellectual intellegience dengan kinerja SDM. Studi lain juga menunjukkan survey kondisi internal organisasi yaitu kompetensi dan kapabilitas yang memiliki pengaruh dengan kinerja organisasi dengan tergantung pada kemampuan adaptasi lingkungan. 
Uraian diatas memperlihatkan bahwa adanya kesimpulan:

H4a, b, c: kinerja SDM dipengaruhi oleh kecerdasan intelektual, emosional juga spiritual dengan dimoderasi IT.

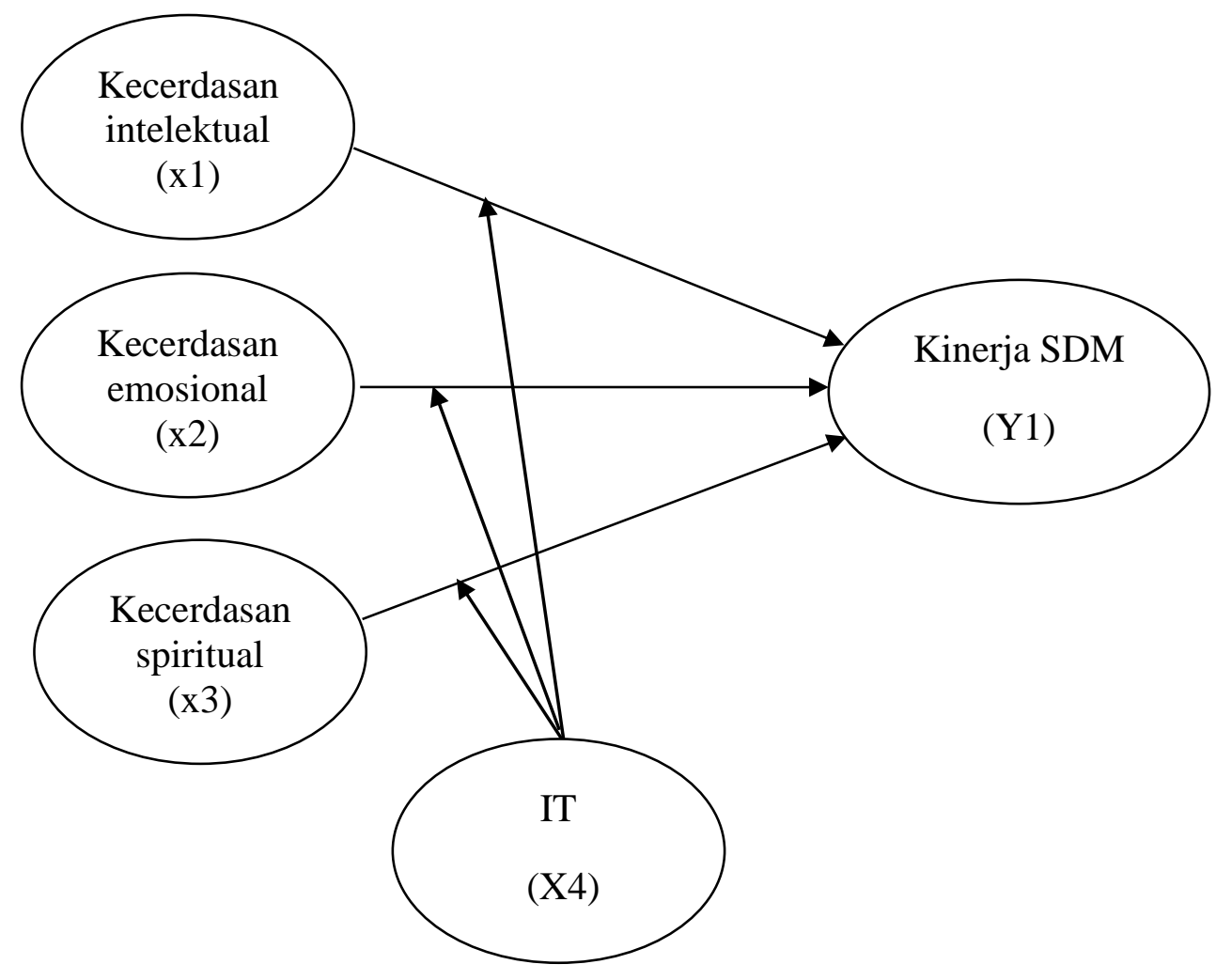

\section{Gambar 1. Model Analisis Regresi Moderating}

Sumber: Boyatzis 2001, Mudali 2002, Zohar \& Marshall 2001, Wiramiharja 2003, Imam Gozali 2009, dan di kembangkan untuk penelitian.

\section{METODE PENELITIAN}

\section{a. Populasi \& Sample}

Populasi beserta sampel yang digunakan merupakan keseluruhan pegawai yang ada di BBWS Pemali Juana Semarang yaitu 227, dan menggunakna perhitungan rumus slovin hingga mengahsilkan 70 responden, dan hanya 63 responden yang mengisi Variable.

\section{b. Metode Pengumpulan Data}

Peneyebaran angket dan kuesioner ke responden serta wawancara sangat diperlukan untuk memperoleh data yang akan dibutuhkan sebagai penunjang penelitian, yaitu dengan menggunakan teknik analisis random sampling.

\section{c. Uji Validitas}

Dalam uji ini akan diketahui konstruk yang diukur, dan untuk menguji analisis validitas diperlukan pengujian homogenitas. Variable digunakan untuk mengukur pertanyaan- 
pertanyaan dalam variable dan nantinya akan di korelasikan dengan jumlah item. Jika korelasinya adalah positif dimana skor item > interkorelasi antar item, bisa dikatakan variable tersebut valid, korelasi ini disebut product moment pearson. Jika corrected item total korelasi $>/=0,41$ pada suatu alat ukur tersebut, maka dikatakan valid, Singgih Santoso (2001).

Tabel 1. Hasil Uji Validitas

\begin{tabular}{|l|c|c|c|c|}
\hline \multicolumn{1}{|c|}{ Nama Variabel } & Indikator & r-hitung & r-tabel & Keterangan \\
\hline Kecerdasan & X1.1 & 0,836 & 0,244 & Valid \\
Intelektual & X1.2 & 0,832 & 0,244 & Valid \\
& X1.3 & 0,773 & 0,244 & Valid \\
\hline Kecerdasan & X2.1 & 0,751 & 0,244 & Valid \\
Emosional & X2.2 & 0,768 & 0,244 & Valid \\
& X2.3 & 0,506 & 0,244 & Valid \\
& X2.4 & 0,827 & 0,244 & Valid \\
& X2.5 & 0,719 & 0,244 & Valid \\
\hline Kecerdasan & X3.1 & 0,807 & 0,244 & Valid \\
Spiritual & X3.2 & 0,713 & 0,244 & Valid \\
& X3.3 & 0,785 & 0,244 & Valid \\
\hline IT & X4.1 & 0,797 & 0,244 & Valid \\
& X4.2 & 0,707 & 0,244 & Valid \\
& X4.3 & 0,745 & 0,244 & Valid \\
& X4.4 & 0,695 & 0,244 & Valid \\
& X4.5 & 0,689 & 0,244 & Valid \\
\hline Kinerja SDM & Y.1 & 0,803 & 0,244 & Valid \\
& Y.1 & 0,800 & 0,244 & Valid \\
& Y.1 & 0,718 & 0,244 & Valid \\
\hline
\end{tabular}

\section{d. Uji realibilitas}

Uji Realibilitas merupakan sebuah ukuran konsistensi variable. (cooper \& emory, 1995) Pada waktu dan kondisi yang berbeda variable yang konsisten mampu digunakan dengan baik. Cronbach alpha digunakan dalam pengujian reliabilitas dipenelitian ini. (singgih santoso, 2001) jika cronbach alpha 0,60 lebih besar maka bisa dikatakan variable. Untuk menghitung realibilitas variable digunakanlah software SPSS 17.0.

Table 2. Hasil Uji Reliabilitas

\begin{tabular}{|l|c|l|}
\hline \multicolumn{1}{|c|}{ Variabel } & Cronbach Alpha & Kriteria \\
\hline Kecerdasan Intelektual & 0,743 & Reliabel \\
Kecerdasan Emosional & 0,757 & Reliabel \\
Kecerdasan Spiritual & 0,654 & Reliabel \\
IT & 0,777 & Reliabel \\
Kinerja SDM & 0,664 & Reliabel \\
\hline
\end{tabular}




\section{e. Pengujian hipotesis}

Penelitian ini menggunakan rumus persamaan melalui uji interaksi atau sering disebut dengan Moderated Regresion Analysis (MRA). MRA merupakan aplikasi khusus regresi berganda linier dimana dalam persamaan regresinya mengandung unsur interaksi (perkalian dua atau lebih 512ariable independen) sebagai berikut (Ghozali, 2006).

Adapun bentuk:

Persamaan satu, $Y=\beta_{1} X_{1}+\beta_{2} X_{2}+\beta_{3} X_{3}$

persamaan dua, $Y=\beta_{1} X_{1}+\beta_{2} X_{2}+\beta_{3} X_{3}+\beta_{4} X_{4}+\beta_{5} X_{1} * X_{4}+\beta_{6} X_{1} * X_{2}+\beta_{7} X_{1} * X_{3}$

Keterangan;

Y (kinerja SDM)

$\mathrm{X} 1$ (intellectual intellegencia)

X2 (emotional intellegencia)

X3 (spiritual intellegencia)

X4 (IT)

$\beta_{1,2,3,4}=$ Koefisien 512ariable

Analisis Regresi moderating adalah IT didalam penelitian ini, dimana analisis ini digunakan untuk mengetahui apakah kuat atau melemah dalam mempengaruhi variable indepeden terhadap variable dependen.

\section{Uji t}

Dalam uji ini akan dilakukan pengujian tingkat signifikansi melalui perbandingan $\mathrm{t}$ dengan $t$ hitung juga dengan $t$ table dimana $=0,05$ menunjukkan:

1) t hitung > t varian, maka Ho ditolak Artinya:

variable endogenus dapat menerangkan variable-variable, dan ada pengaruh diantara dua variable yang diuji.

2) thitung < t varia, maka H0 diterima Artinya:

variable endogenus tidak dapat menerangkan variable-variable, dan tidak ada pengaruh diantara dua variable yang diuji.

\section{Uji f}

Pengujian dilakukan melalui uji $\mathrm{F}$ dengan membandingkan $\mathrm{F}$ hitung (observasi) dengan $\mathrm{F}$ varian pada $=0,05$. Jika dalam pengujian menghasilkan:

F hitung > F 512aria, maka H0 ditolak Artinya :

variasi dari model regresi berhasil menerangkan variable bebas secara keseluruhan, sejauh mana pengaruhnya terhadap variable terikat.

F hitung < F table, maka Ha ditolak artinya: 
variasi dari model regresi berhasil menerangkan variable bebas secara keseluruhan, tidak berpengaruh terhadap variable terikat.

\section{Koefisien determinasi}

Koefisien determinasi berganda (R2) digunakan untuk mengetahui variable bebas dalam menerangkan variable tidak bebas. Semakin besar mendekati satu, makan akan memperoleh R2 dan variable bebas akan semakin besar mempengaruhi variable terikat. Namun sebaliknya, semakin kecil sumbangan variable bebas ke variable terikat, semakin kecil pula R2 nya. Jadi secara general koefeisien determinasi berganda ini ada di antara $0 \& 1$ atau $0 \leq \mathrm{R} 2 \leq 1$.

\section{HASIL DAN PEMBAHASAN}

Berdasarkan analisis regresi :

$1 . \mathrm{Y}=0,258 \mathrm{X}_{1}+0,350 \mathrm{X}_{2}+0,342 \mathrm{X}_{3}$

2. $Y=0,224 X_{1}+0,250 X_{2}+0,222 X_{3}+0,261 X_{4}+0,216 X_{1} * X_{4}-0,071 X_{1} * X_{2}-0,054 X_{1} * X_{3}$

\section{a. Nilai koefisien regresi persamaan 1,}

Dalam persamaan ini menunjukkan ketiga kecerdasan memiliki pengaruh yang positif dan dapat di artikan semakin tinggi kinerja SDM dikarenakan pengaruh dari variable kecerdasan yang semakin baik.

\section{b. Nilai koefisien regresi persamaan 2 ,}

Di persamaan ini menunjukkan hanya kecerdasan intelektual saja yang memiliki pengaruh positif terhadap kinerja SDM, sedangkan kecerdasan emosional dan spiritual memilik pengaruh yang negative dengan melalui IT sebagai moderating nya yang tidak memoderasi secara signifikan. 


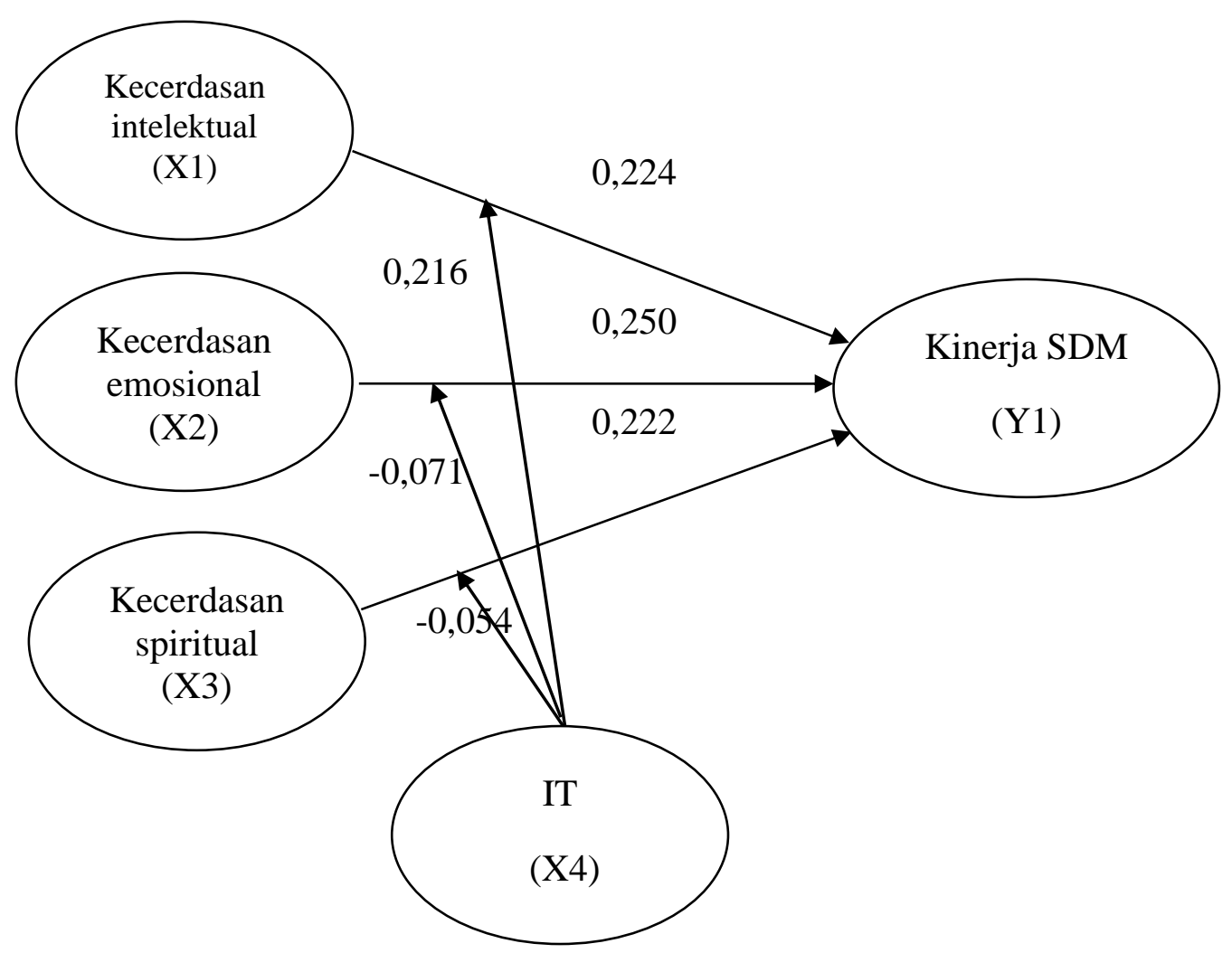

Gambar 2. Hasil Analisis Regresi

\section{PENUTUP}

Dari kesimpulan hipotesis pertama adalah dimana intellectual intellegencia memiliki pengaruh positif terhadap kinerja SDM pada pegawai BBWS Pemali Juana Semarang. Artinya apabila semakin tinggi kecerdasan Intelektual maka semakn baik kinerjanya. Karena adanya SDM yang berkualitas menjadikan instansi tersebut menjadi lebih mempunyai banyak pegawai yang memiliki kecerdasan yang luar biasa, cerdas dalam mengambil keputusan secara musyawarah, cerdas dalam berbasa yang baik, juga cerdasa dalam mengatur segala keuangan yang ada dalam pekerjaan. Setelah itu terdapat pengaruh positif antara emotional intelligence dengan kinerja SDM pada pegawai BBWS Pemali Juana Semarang. Artinya apabila semakin tinggi kecerdasan emosional yang di miliki oleh pegawai maka akan semakin baik kinerja SDM tersebut. Oleh adanya hal itu, semua pegawai menjadi semakin percaya diri, juga mampu memotivasi diri mereka sendiri dalam mengahadapi sebuah pekerjaan, saling mampu memahami sesama rekan kerja dan juga mampu menjaga hubungan baik dengan sesama rekan kerja. Menghasilkan pengaruh positif antara spiritual intellegencia terhadap kinerja SDM pada pegawai BBWS pemali juana semarang. Karyawan yang memiliki kemampuan spiritual baik pasti akan berkinerja baik, karena dengan kecerdasan yang dimiiki itu pegawai juga akan selalu merasa menjadi diri yang selalu berfikir positif, juga memiliki rasa tanggung jawab pada 
pekerjaan yang di embannya. Ada pengaruh positif dan negatif dalam hasil kali ini. Dimana pengaruh kecerdasan intelektual memiliki pengaruh yang positif terhadap kinerja SDM, sedangkan kebalikan dari itu kecerdasan emosional \& spiritual memiliki pengaruh negative, dikarenakan variable moderating tidak memodari secara signifikan dalam pengujiannya. Jika dilihat dalam hasil penelitian sebelumnya atau teori yang ada, IT sangat memiliki pengaruh yang baik (positif) terhadap kecerdasan dengan kinerja SDM, namun di sisi lain hasil yang disebarkan menghasilkan keterbalikan dari penelitian yang terdahulu dimana hanya kecerdasan intelektual saja yang memiliki pengaruh positif, sedangkan emosional \& spiritual memiliki pengaruh negative.

Penelitian ini memiliki keterbatasan didalam penggunaan variable IT tidak memberikan pengaruh yang kuat, maka dari itu dari penelitian ini diharapkan dari organisasi dapat meningkatkan IT dalam pekerjaan sehari hari melihat bahwa dari segi teori seharusnya IT dapat mempengaruhi kecerdasan terhadap kinerja SDM.

Saran penelitian ini mungkin harus mengganti salah satu variable independen yaitu variable kecerdasan spiritual untuk digantikan dengan variable stress kerja, karena jika dilihat penelitian yang dilakukan ini, adanya variable IT tidak begitu mempengaruhi variable kecerdasan spiritual, karena SDM yang berkualitas rendah biasanya diakarenakan banyaknya pekerjaan yang dikerjakan sehingga tidak maksimal dalam melaksankaan pekerjaan dan mengakibatkan stress kerja. 


\section{DAFTAR PUSTAKA}

Agustian, A.G. (2001). Rahasia sukses membangun kecerdasan Emosi dan Spiritual (ESQ). Jakarta: Arga Wijaya Persada.

Awangga. (2006). Analisis Pengaruh Kecerdasan Emosional dan Kecerdasan Spiritual terhadap Kinerja Karyawan. Disertasi. Universitas Diponegoro, Semarang.

Boyatzis. (2001). Unleashing the Power of Self Directed Learning. Cleveland, Ohio, US: CaseWestern Reserve University.

Dewi, A.A.I.S., and Darma, G.S. (2017). Proses Rekrutmen, Seleksi, Pelatihan, Penempatan dan Kinerja Karyawan, Jurnal Manajemen \& Bisnis, 14 (1): 1-18.

Emmons, R.A. (2000). Is Spiritually Intelligence?, The Internatinal Journal for The Psyhology of Religion.

Gozali, I. (2001). Aplikaasi Analisis Multivariat dengan Program SPSS. Semarang: Badan Penerbitan Universitas Diponegoro.

Mangkunegara. (2001). Karakteristik Kinerja Karyawan. www.kajianpustaka.com/html $>[01,11,14]$.

Mathis. (2009). Seri Manejemen Sumber Daya Manusia, Cet.4. Jakarta: PT. Elex Media Komputindo.

Mujib, A., \& Muzakir, J. (2002), Nuansa-nuansa Psikologi Islam, cet.1. Jakarta: PT. Raja Grafindo Persada.

Robbins, S.P. (2001). Perilaku Organisasi. Jakarta: PT. Prehallindo.

Sinamo, J, H. (2002). Ethos 21: Etos Kerja Profesional di Era Digital Global. Jakarta: Institut Dharma Mahardika.

Tjhai, F.J. (2003). Analisis Faktor-Faktor yang Mempengaruhi Pemanfaatan Teknologi Informasi dan Pengaruh Pemanfaatan Teknologi Informasi Terhadap Kinerja Akuntan Publik, Jurnal Bisnis dan Akuntansi.

Wiandari, I.A.A., and Darma, G.S. (2017). Kepemimpinan, Total Quality Management, Perilaku Produktif Karyawan, Kinerja Karyawan dan Kinerja Perusahaan, Jurnal Manajemen \& Bisnis, 14 (2): 61-78.

Widiyanti, E. (2003). Analisis Pengaruh Kompetensi Komunikasi, Kecerdasan Emosional, dan Budaya Organisasi terhadap Kinerja Karyawan, Universitas Diponegoro, Semarang.

Widodo. (2012). Cara Baru Memeberdayakan Diri Untuk Bahagia, Sukses dan Sejahtera, Jakarta: PT. Gramedia Pustaka Utama.

Wiramiharja, S.A. (2003). Keeratan Hubungan Antara Kecerdasan, Kemuan, Dan Prestasi Kerja, Jurnal Psikologi, 11 (1). 
Jurnal Manajemen Bisnis

Volume 17, No. 4, Oktober 2020

ISSN : 1829-8486 (print) | ISSN : 2528-1216 (online) http://journal.undiknas.ac.id/index.php/magister-manajemen/

Zohar, D., \& Marshall, I. (2001). Spiritual Intelligence: The Ultimate Intelligence. New York: Bloomsbury. 